\title{
Effect of Physically Programmed Examination to Value of Maximum Oxygen Volume (Vo2max) at Justice Cricket Junior Samarinda
}

\author{
$1^{\text {st }}$ Muhammad Ramli Buhari \\ Universitas Mulawarman \\ Samarinda, Indonesia
}

\author{
$2^{\text {nd }}$ Hasan \\ Universitas Al Asyariah Mandar \\ Polewali Mandar, Indonesia \\ hasansulbar702@gmail.com
}

\begin{abstract}
VO2max is an important factor that contributes to the endurance of aerobic athletes. It reflects the cardiorespiratory capacity of a person, so the more oxygen that can be transported and consumed by the muscles that are on the move, the better the endurance of the athlete. The purpose of this study was to prove the usefulness of physical exercise programmed against the VO2max value of female athletes age 10-12 years. The study sample consisted of 40 female athletes age 10-12 years who were divided into 2 groups, namely control and treatment group. VO2max values were measured before and after the subjects performed a 12-week programmed physical exercise, using the modified Queen's College Step test method. The unpaired t-test is used to compare changes in VO2max values between groups. There is an increase in VO2max value in female athletes age 10-12 years who received a programmed physical exercise.
\end{abstract}

Keywords-vo2max, programmed physical exercise, female cricket athlete

\section{INTRODUCTION}

In the development of medical science, sport has got a place in the world of health as one important factor in the prevention of disease. Someone who has a prime physical fitness can perform daily activities optimally and do not tire quickly, and still have energy reserves to perform other activities [1]

One of the new sports and started a lot of popular community is a sport cricket, this sport can not be separated from the need for good physical fitness. One element of physical fitness is cardiorespiratory endurance. Basically, there are two kinds of cardiorespiratory endurance, namely aerobic and anaerobic. During cricket play, it takes anaerobic endurance to perform explosive movements that require an explosion of energy. But for the game in general, movement patterns, as well as recovery time, aerobic endurance is needed. Measurement of cardiorespiratory endurance for aerobic capacity can be performed by measuring maximal oxygen consumption (VO2max).

VO2max is the maximum amount of oxygen that can be consumed during intense physical activity until eventually fatigue occurs [3]. VO2max values depend on cardiovascular, respiratory, hematologic, and muscle oxidative abilities [4]. Physical fitness is the dynamic degree of a person who is the basis for the successful execution of the task to be performed. Therefore, absolutely necessary coaching and maintenance of one's physical fitness. For the successful implementation of this task needs to be a match between the requirements that must be met that is anatomical and physiological to the kind and intensity of physical tasks performed. Skill related fitness is defined as skills that support one's performance in sports and other physical activities. Included in related fitness skills are agility, balance, coordination, reaction time, speed, and power [7].

\section{A. Cardiorespiratory Endurance}

Cardiorespiratory endurance is the body's ability to perform intense and sustained physical activity by involving a large group of muscles. This cardiorespiratory endurance includes the most important element of physical fitness. Exercise to improve cardiorespiratory endurance can lead to increased aerobic capacity of a person [8].

\section{B. Factors Affecting VO2max Value}

Some factors that may affect the $\mathrm{VO} 2 \mathrm{max}$ value are as follows:

1. Age

Cross-sectional and longitudinal studies of VO2max values in untreated 8-16 year-olds show progressive and linear increases from the peak of aerobic ability, with respect to chronological age in girls and boys. VO2max boys become taller by the age of 10, although some believe exercise resistance is not affected by aerobic ability before age 11. The peak VO2max score was achieved approximately at age 18-20 years in both sexes.

In general, aerobic ability drops slowly after the age of 25 years. Research from Jackson AS et al. found that the mean reduction in $\mathrm{VO} 2 \mathrm{max}$ per year was $0.46 \mathrm{ml} / \mathrm{kg} / \mathrm{min}$ for men $(1.2 \%)$ and $0.54 \mathrm{ml} / \mathrm{kg} / \mathrm{min}$ for women $(1.7 \%)$. This decrease occurs due to several things, including maximum heart rate reduction and maximum stroke heart rate.

2. Gender 
Women's aerobic ability is about $20 \%$ lower than men of the same age. This is due to hormonal differences that cause women to have lower hemoglobin concentrations and greater body fat. Women also have less muscle mass than men. From the age of 10 years, VO2max boys become $12 \%$ higher than girls. At age 12, the difference is $20 \%$, and at 16 years of age $\mathrm{VO} 2 \mathrm{max}$ boys are $37 \%$ higher than girls.

3. Temperature

In the luteal phase of menstruation, progesterone levels increase. Though progesterone has a thermogenic effect, which can increase the body's basal temperature. The thermogenic effect of this progesterone seems to increase BMR, so it will affect the cardiovascular work and ultimately also affect the value of VO2max. Thus, indirectly, the temperature change will affect the value of VO2max.

4. State of the exercise

Physical exercise can increase the VO2max value. However, VO2max is not fixed to a certain value, but can change according to the level and intensity of physical activity. For example, the old bed-rest can lower VO2max between $15 \%-25 \%$, while regular intense regular exercise can raise VO2max with almost similar values.

Effective physical exercise is endurance and includes a certain duration, frequency, and intensity. So that can be said that the activity and background of an athlete's exercise can affect its VO2max value.

\section{Factors Determining the VO2max Value \\ 1. Pulmonary function}

During intense physical activity, there is an increased need for oxygen by the muscles at work. This oxygen requirement is obtained from ventilation and oxygen exchange in the lungs. Ventilation is a mechanical process for inserting or removing air from the lungs.

2. Cardiovascular function

The most important cardiovascular response to physical activity is an increase in cardiac output. This increase is due to an increase in the stroke volume of heart and heart rate which can reach about $95 \%$ of its maximum level. Because oxygen consumption by the body can not exceed the speed of the cardiovascular system by delivering oxygen to the tissues, it can be said that the cardiovascular system may limit the VO2max.

3. Red blood cells (Hemoglobin)

4. Body composition

Fatty tissue gains weight, but does not support the ability to directly use oxygen during heavy exercise. Thus, if VO2max is expressed relative to body weight, the weight of the fat tends to increase the denominator without causing any effect on the VO2 numerator; $\mathrm{VO} 2(\mathrm{mk} / \mathrm{kg} / \mathrm{min})=$ VO2 (LO2) x 1000 Weight (kg)

Thus, obesity tends to reduce $\mathrm{VO} 2 \mathrm{max}$.

\section{VO2max measurements}

To measure VO2max, there are several tests that are commonly used. These tests should be measurable and easy to implement, and require no special skills to do so. Bicycle and treadmill ergometer tests are the two most commonly used ways of generating workloads. Even so, step test or field test can also be done for the same benefit. 1. Bicycle Ergometer
Performed by using a static bicycle pedaled to get the workload. Workload can be provided continuously or intermittently. This bicycle ergometer can be mechanical or electrical, and can be used in both perpendicular and supine positions.

\section{Treadmill}

Some of the protocols that can be used in inspection with treadmills are: (1) Mitchell Method, Sproule, and Chapman, (2) Saltin-Astrand Method, and (3) OSU Method. 3. Field Test

This test is very easy to do, because it does not require special tools. Testee is only required to run by a certain distance or time. Some variations of this test are: (1) 12 minute run, (2) 1.5 mile run, and (3) $2.4 \mathrm{~km}$ run test.

\section{Step Test}

Many variations of this test with respect to the number of steps per minute and the height of the bench used to generate the workload. Testee moves up and down the bench alternating legs with a rhythm that is set with a metronome. Although it is easy to do and does not cost much, the exact workload is hard to come by with this test because fatigue that may arise during a test can affect the accuracy of the workload and the point of gravity. VO2max values can be obtained with the Astrand normogram based on pulse and weight or using formula calculations. The available formulas also vary, with the standard VO2max values vary as well. The data needed to calculate VO2max is a recovery heart rate. Some variations include: (1) Harvard Step Test, (2) Queen's College Step Test, (3) Tuttle Step Test, (4) Ohio Step Test, (5) YMCA Step test, and (6) Tecumseh Step Test.

\section{E. Physical Exercise Physically}

What is meant by physical exercise is programmed physical exercise that is done regularly with the intensity, frequency, and duration of a certain, and have a specific purpose as well.

\section{Exercise intensity}

Athletes should be given training until their heart rate reaches $80-95 \%$ of the maximum heart rate. While the maximum heart rate that can be achieved during the exercise is 220 - age (in years). An $80-95 \%$ heart rate of the maximal heart rate is called the target zone. If the intensity of the exercise given is less than the target zone, then the results do not improve much endurance.

\section{Duration of Exercise}

Duration of exercise should range between 40-45 minutes within the target zone if it is to achieve endurance improvement. This does not include warm-up and cooling times.

\section{Frequency of Exercise}

We recommend that you practice at least 3 times a week to get good results because endurance someone will start to fall after 48 hours if not undergoing exercise. For an athlete, the higher the required endurance factor in the branch, the higher the VO2max number it should have. In this study to be used is a method of Queen's College Test with a modified bench made as high as $28 \mathrm{~cm}$. 


\section{MATERIALS AND METHOD}

This research is a quasi experimental research with the design of Two Group Pre and Post Test Control Group Design;

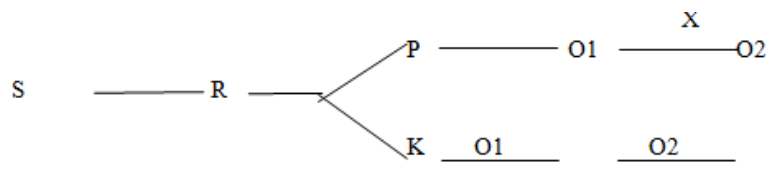

Fig 1. Design of quasi experimental method

Information :

S: Subject R: Random P: Treatment group K: Control group, O1: Measurement of endurance before treatment. O2: Measurement of endurance after treatment for 12 weeks

$\mathrm{X}$ : Programmed physical training

The target population in this study were girls who are athletes cricket junior daughter Samarinda age group 10-12 years and follow the physical exercise programmed during the month of January-March 2017 as treatment group, as well as elementary school students 031 Samarinda which has been selected through inclusion and exclusion criteria.

The sample selection was done by simple random sampling. The sample size is 20 people per group. The independent variables in this study are physical exercise programmed athletes cricket junior daughter of Samarinda. Physical exercise is an exercise that is done regularly with the intensity, frequency, and duration particular, according to the program that has been set. Using a nominal scale. Variable depending on this research is $\mathrm{VO} 2 \mathrm{max}$ value. Measured using the Queen's College Step Test. Using continuous scale.

The result data is VO2max edited, coded, and dientry in computer file using SPSS 15.0 for Windows program. After cleaning, statistical analysis is tested using descriptive analysis test and inferential test analysis. All data distributions were tested for normality using the SaphiroWilk test. In characteristic data, it was found that age data and BMI had normal distribution, so continued with t-test was not paired and the result was that the two groups were not significantly different.
The difference in initial and final VO2max values in both groups was tested using the Wilcoxon test because the VO2max value had abnormal data distribution. It was found that the difference between initial and final VO2max values in each group had a significant difference. The $p$ value is considered significant when $\mathrm{p}<0.05$.

\section{RESULTS AND DISCUSSION}

There were 40 subjects who met the inclusion criteria. The subjects were divided into two groups, namely the treatment group and the control group, using simple random sampling. Initially, data collection of research subject characteristics was done. The data was collected on the initial $\mathrm{VO} 2 \mathrm{max}$ value. The treatment group performed a programmed physical exercise for 12 weeks, while the control group did not perform the programmed physical exercise. After 12 weeks, the final VO2max data is taken. The number of study subjects did not change until the end of the study.

The results showed that the study subjects had almost the same age, in which the treatment group had a slightly older age than the control group. In the results of weight and height measurements there was a significant difference between the two groups, ie the treatment group had body weight and height greater than the control group. But the difference in body weight and height is not too affect the overall research results because in the end BMI both groups are not significantly different.

VO2max measurements were performed using the Queen's College Step Test method with modified bench height, performed 2 times over an interval of 12 weeks.

It can be seen that the mean initial VO2max values in the treatment group were lower than the control group. In contrast, the final VO2max value in the treatment group was higher than the control group. From the results can be seen also that there is a change in $\mathrm{VO} 2 \mathrm{max}$ value in both groups. The control group experienced a significant decrease in VO2max value, while the treatment group experienced a significant increase in VO2max value.

TABLE I. CHARACTERISTICS OF RESEARCH SUBJECT

\begin{tabular}{|c|c|c|c|c|c|}
\hline Measurement & $\begin{array}{c}\text { Control Group } \\
\text { (Average) }\end{array}$ & $\begin{array}{c}\text { Standard } \\
\text { Deviation }\end{array}$ & $\begin{array}{c}\text { Treatment } \\
\text { Group } \\
\text { (Average) }\end{array}$ & $\begin{array}{c}\text { Standard } \\
\text { Deviation }\end{array}$ & $\mathrm{p}$ \\
\hline Age (years) & 11,65 & 0,81 & 11,70 & 0,92 & $0,976 \S$ \\
\hline Weight $(\mathrm{kg})$ & 36,85 & 10,54 & 42,75 & 7,47 & $0,048^{*}$ \\
\hline Height $(\mathrm{cm})$ & 142,16 & 9,19 & 151,21 & 8,49 & $0,003^{*}$ \\
\hline BMI $(\mathrm{kg} / \mathrm{m} 2)$ & 17,94 & 3,51 & 18,58 & 2,18 & $0,493^{*}$ \\
\hline
\end{tabular}

TABLE II. VO2MAX VALUE BEGINNING AND END

\begin{tabular}{|c|c|c|c|c|c|}
\hline $\begin{array}{c}\text { VO2max } \\
(\mathrm{ml} / \mathrm{kg} / \mathrm{min})\end{array}$ & $\begin{array}{c}\text { Control } \\
\text { Group } \\
\text { (Average) }\end{array}$ & $\begin{array}{c}\text { Standard } \\
\text { Deviation }\end{array}$ & $\begin{array}{c}\text { Control Group } \\
\text { (Average }\end{array}$ & $\begin{array}{c}\text { Standard } \\
\text { Deviation }\end{array}$ & $\mathrm{p}$ \\
\hline VO2max start & 44,38 & 3,85 & 39,91 & 4,50 & $0,002^{*}$ \\
\hline VO2max end & 36,96 & 5,63 & 42,53 & 4,68 & $0,003 \S$ \\
\hline $\mathrm{P}$ & $0,001 £$ & - & $0,045 \approx$ & - & - \\
\hline $\begin{array}{c}\text { Delta VO2max } \\
(\mathrm{ml} / \mathrm{kg} / \mathrm{min})\end{array}$ & $-7,42$ & 6,46 & 2,62 & 5,03 & $<0,001^{*}$ \\
\hline
\end{tabular}


From the research data obtained that there is an increase in VO2max value in the treatment group, the junior sickle cricket athletes Samarinda age group 10-12 years after doing the physical exercise programmed. While in the control group, namely elementary school students 031 Samarinda actually decreased VO2max value. Increased $\mathrm{VO} 2 \mathrm{max}$ values in the treatment group who performed the programmed physical exercise in accordance with some similar studies that have been done previously. This increase is influenced by several things: physical exercise, cardiovascular function, and body composition.

Theoretically, the control group should have an increased VO2max value because VO2max values will increase with age (35). However, this can not be used as a base when the study time is only 12 weeks In addition, it should be considered also non-physical factors, namely the psychological condition of research subjects. One of the main problems in sub maximal exercise tests such as this step test is the lack of motivation of research subjects to perform the test. The differences in physical endurance among individuals are not only related to physical capacity alone, but also relate to the psychic capacity to suppress the symptoms and manifestations of fatigue that arise, where psychological endurance is lower in those with less physical endurance.

The subjects for the control group were elementary school students whose physical activities were limited to daily living activities, while the subjects for the treatment group were junior cricket athletes who had grown accustomed to regular physical practice. Thus, the motivation for performing this test in the control group was more unstable than the treatment group, so the control group's VO2max value decreased.

\section{CONCLUSION}

The programmed physical exercise for 12 weeks can significantly increase $\mathrm{VO} 2 \max$ value. Beside that, there was a significant difference in VO2max value changes between groups who received a 12-week programmed physical exercise with a group that did not get a programmed physical workout. The group that did not get the programmed fiscal exercise decreased significant VO2max value.

It is needed to do more research with the characteristics of subjects more controlled and doing research on VO2max by taking into account puberty factor to get more accurate results.

\section{REFERENCES}

[1] Giriwijoyo, Santoso, H.Y.S, "Health and sports science", Sport Medicine. Bandung: Sports and Health Education Teaching Team of UPI, 2007.

[2] Sukmaningtyas H, Pudjonarko D, Basjar E, "The influence of aerobic and anaerobic training to cardiovascular system and the reaction speed", Medika Media: Indonesia, 2004.

[3] Fraser GE, Philips RL, Harris R, "Physical Fitness And Blood Pressure In School Children Circulation", 2009

[4] Rodrigues AN, Perez AJ, Carletti L, Bissoli NS, Abreu GR, "Maximum oxygen uptake in adolescents as measured by cardiopulmonary exercise testing: a classification proposal", Journal de Pediatria, 2006

[5] Bompa, Tudor O, "Theory and methodologi of training", United States of America: Kendall/Hunt Publising Company, 1990.

[6] Welsman JR, Armstrong N, "The measurement and interpretation of aerobic fitness in children: current issues", Journal of the Royal Society of Medicine, 2008.

[7] Vander et al, "Human physiology: the respiratory system. in: human physiology the mechanism of body function, 8nd ed", Boston: McGraw-Hill, 2011.

[8] Fox SI, "Muscle: mechanism of contraction and neural control. in: fox si. human physiology, 8nd ed", Kota: McGraw-Hill, 2009.

[9] Armstrong N, Welsman JR, "Assessment and interpretation of aerobic fitness in children and adolescents", Exer Sport Scien Ver, 1994.

[10] Solomon SJ, Kurzer MS, Calloway DH, "Menstrual cycle and basal metabolic rate in women", Am J Clin Nutr, 2011.

[11] Pate R, McClenaghan B, Rotella R, "The distribution and use of oxygen in dwijowinoto k (translator). basic of coaching sciences", Philadelphia (USA): Saunders College Publishing, 2008.

[12] Verducci F, "Measurement concepts in physical education", Missouri (USA), 1980 